\title{
DISTRIBUTION PATTERN OF RARE EARTH ELEMENTS IN SOFT TISSUE OF SACCOSTREA CUCULLATA IN TERENGGANU AND EAST JOHOR COASTAL WATERS
}

\author{
Nik Nurizni Nik Ali ${ }^{1}$, Siti Nabila Mat Ali ${ }^{1}$, Muhammad Farhan Kammoo' ${ }^{1}$, Mohd Fuad Miskon ${ }^{2 *}$ \\ ${ }^{1}$ Department of Marine Science, Kulliyyah of Science, International Islamic University Malaysia, 25200 Kuantan, Malaysia. \\ ${ }^{2}$ Institute of Oceanography and Maritime Studies (INOCEM), Kulliyyah of Science, International Islamic University Malaysia, 25200 Kuantan, \\ Malaysia. \\ *Corresponding author email: fuadm@iium.edu.my
}

This is an open access article distributed under the Creative Commons Attribution License, which permits unrestricted use, distribution, and reproduction in any medium, provided the original work is properly cited.

\section{ARTICLE DETAILS}

\section{Article History:}

Received 01 February 2019 Accepted 14 March 2019 Available Online 10 June 2019

\section{ABSTRACT}

This study determined the concentration and accumulation pattern of REEs in the soft tissue of Saccostrea cucullata with respect to interspatial variability. Variability in the concentration of REEs in soft tissue of $S$. cucullata was observed in all samples with significant differences among samples associated with sampling sites $(p<0.05)$. The distribution pattern of REEs' concentration in soft tissue of $S$. cucullata is uniformly distributed among sampling sites with enrichment of light REE, LREE over heavy REE, HREE. The same accumulation pattern indicate that REEs are transported as a coherent group in aquatic ecosystem. All REEs yielded positive correlation among each elements in the soft tissue of $S$. cucullata. Average distribution of REEs in soft tissue of $S$. cucullata indicated that East Johor has the most abundance of REEs' concentration compared to Terengganu coastal water. This occurrence probably due to higher urbanization and industrialization activities such as sewage and effluent wastes. ST10 located in East Johor region has the most abundance of REEs while ST4 located in Terengganu region has the lowest concentration of REEs with Ce as the most abundance element and Dy as the least abundance element. The distribution pattern of REEs' concentration in this study is slightly different. There is significant differences between concentration of all REEs in the soft tissue of S. cucullata in the year of 2013 and 2017 except for La, Ce and Nd (p < $0.05)$.

\section{KEYWORDS}

Saccostrea cucullate, aquatic ecosystem, higher urbanization, abundance element.

\section{INTRODUCTION}

The rare earth elements (REE) consist of seventeen chemical elements: fifteen lanthanides; lanthanum (La), cerium (Ce), praseodymium (Pr), neodymium $(\mathrm{Nd})$, promethium $(\mathrm{Pm})$, samarium $(\mathrm{Sm})$, europium $(\mathrm{Eu})$, gadolinium (Gd), terbium (Tb), dysprosium (Dy), holmium (Ho), erbium (Er), thulium (Tm), ytterbium (Yb), lutetium (Lu)], scandium (Sc) and yttrium (Y). Sc and $Y$ are considered REE because they tend to exist in the same ore deposits with the lanthanides and exhibit similar chemical properties. La, Ce, Pr, Nd, Sm, Eu are indicated as light REE due to their atomic mass lower than 153 while Gd, Tb, Dy, Ho, Er, Tm, Yb and Lu are indicated as heavy REE because of their atomic mass greater than 153 $[1,2]$. The name of rare earth elements itself is a misnomer due to their abundant existence in the earth's crust and not especially rare as it named. In the Earth's crust, the estimated average concentration of the rare earth elements (REEs) is 150 to $220 \mathrm{mg} \mathrm{kg}-1$ with Ce as the most abundant element in the earth's crust at $60 \mathrm{mg} \mathrm{kg}^{-1}$ and $\mathrm{Tm}$ and Lu as the least abundant ones at $0.5 \mathrm{mg} \mathrm{kg}^{-1}[3,4]$. However, these elements tend to occur together in nature thus, make it quite difficult to separate them from one another and find them in quantities significant enough to support their current heightened demand. Their unique physical and chemical properties have rendered them indispensable in a growing number of critical technologies [5].

REEs are widely used in areas of agriculture, national defense, new energy, biological medicine, aerospace and the nuclear industry as well as in daily life [6,7]. For example; fertilizers, automotive catalysts, luminescent materials, high-performance permanent magnets, contrast agents in biomedical imaging, antitumor medicine and nuclear radiation detector $[8,9]$. These elements have been characterized neither as essential elements for life nor as strongly toxic elements in the environment. Although the environmental toxicity of REEs is largely unknown, environmental contamination has already been found in some mineralized areas as well as soils that are affected by the long-term application of sludge. REEs in soil and water are released and partly enter human body through multiple exposure pathways, especially food ingestion. As nonessential elements in organisms, the effects of REE accumulation on organisms remain fragmentary and inconsistent. Furthermore, the toxicological mechanisms and related environmental risk remain unclear [10]. Although there is no report on incidents of human poisoning through food chain, potential concerns regarding effects of continuous exposure to low levels of REEs on human health have been arising. This is due to their accumulation in blood, brain, lung, lymph nodes and bone after entering human body and long-term exposure to REE may be related to health problems such as changes in brain and bone [11-13]. REEs also have been proven to being accumulated by biota and have toxic effects similar to heavy metals [14].

Therefore, monitoring on REEs distribution and behaviour through biomonitoring is essential in assessing environment response including human exposures to natural and synthetic chemicals, based on analysis of an individual organism's tissues [15]. Mussels or other bivalves species such as oyster and clams are commonly preferred for biomonitoring of aquatic metal pollution and are enclosed as the biomonitors for the 
evaluation of heavy metals pollution in marine waters because of their advantages over the other organisms; wide geographical distribution, abundance, sedentary habit, tolerance to high concentrations of most environmental contaminants and their high bioconcentration factors for pollutants [16-18]. The use of bivalve and gastropods bioindicators to study pollution in the Malaysian environment has received much attention but not on the distribution and behaviour of REEs [18-21].

\section{METHODOLOGY}

Table 1: Location of sampling sites along Terengganu and East Johor coastal water.

\begin{tabular}{|l|l|l|}
\hline Station & Location & Coordinate \\
\hline \multirow{2}{*}{ ST1 } & \multirow{2}{*}{$\begin{array}{l}\text { Bukit } \\
\text { Kluang }\end{array}$} & $5^{\circ} 47^{\prime} 42.50^{\prime \prime} \mathrm{N}$ \\
\cline { 3 - 3 } & & $102^{\circ} 36^{\prime} 35.01^{\prime \prime} \mathrm{E}$ \\
\hline \multirow{2}{*}{ ST2 } & \multirow{2}{*}{$\begin{array}{l}\text { Bari } \\
\text { Kecil }\end{array}$} & $5^{\circ} 34^{\prime} 0.60^{\prime \prime} \mathrm{N}$ \\
\cline { 3 - 3 } & & $102^{\circ} 51^{\prime} 55.57^{\prime \prime} \mathrm{E}$ \\
\hline \multirow{2}{*}{ ST3 } & \multirow{2}{*}{$\begin{array}{l}\text { Tanjung } \\
\text { Jara }\end{array}$} & $4^{\circ} 48^{\prime} 45.88^{\prime \prime} \mathrm{N}$ \\
\cline { 3 - 3 } & & $103^{\circ} 25^{\prime} 26.83^{\prime \prime} \mathrm{E}$ \\
\hline \multirow{2}{*}{ ST4 } & \multirow{2}{*}{ Paka } & $4^{\circ} 37^{\prime} 47.77^{\prime \prime} \mathrm{N}$ \\
\cline { 3 - 3 } & & $103^{\circ} 26^{\prime} 14.53$ "E \\
\hline \multirow{2}{*}{ ST5 } & \multirow{2}{*}{ Kemasik } & $4^{\circ} 27^{\prime} 22.06^{\prime \prime} \mathrm{N}$ \\
\cline { 3 - 3 } & & $103^{\circ} 26^{\prime} 41.20 " \mathrm{E}$ \\
\hline
\end{tabular}

\begin{tabular}{|l|l|l|}
\hline Station & Location & Coordinate \\
\hline \multirow{2}{*}{ ST6 } & \multirow{2}{*}{$\begin{array}{l}\text { Telaga } \\
\text { Simpul }\end{array}$} & $4^{\circ} 14^{\prime} 43.97^{\prime \prime} \mathrm{N}$ \\
\cline { 3 - 3 } & & $103^{\circ} 26^{\prime} 32.74 " \mathrm{E}$ \\
\hline \multirow{2}{*}{ ST7 } & \multirow{2}{*}{ Mersing } & $2^{\circ} 25^{\prime} 45.84^{\prime \prime} \mathrm{N}$ \\
\cline { 3 - 3 } & & $103^{\circ} 50^{\prime} 52.08^{\prime \prime} \mathrm{E}$ \\
\hline \multirow{2}{*}{ ST8 } & \multirow{2}{*}{$\begin{array}{l}\text { Sedili } \\
\text { Kechil }\end{array}$} & $1^{\circ} 50^{\prime} 36.96^{\prime \prime} \mathrm{N}$ \\
\cline { 3 - 3 } & & $104^{\circ} 8^{\prime} 57.48^{\prime \prime} \mathrm{E}$ \\
\hline \multirow{2}{*}{ ST9 } & \multirow{2}{*}{$\begin{array}{l}\text { Tanjung } \\
\text { Balau }\end{array}$} & $1^{\circ} 36^{\prime} 47.52^{\prime \prime} \mathrm{N}$ \\
\cline { 3 - 3 } & & $104^{\circ} 15^{\prime} 33.48^{\prime \prime} \mathrm{E}$ \\
\hline \multirow{2}{*}{ ST10 } & \multirow{2}{*}{$\begin{array}{l}\text { Batu } \\
\text { Layar }\end{array}$} & $1^{\circ} 26^{\prime} 48.12^{\prime \prime} \mathrm{N}$ \\
\cline { 3 - 3 } & & $104^{\circ} 17^{\prime} 43.08^{\prime \prime} \mathrm{E}$ \\
\hline
\end{tabular}

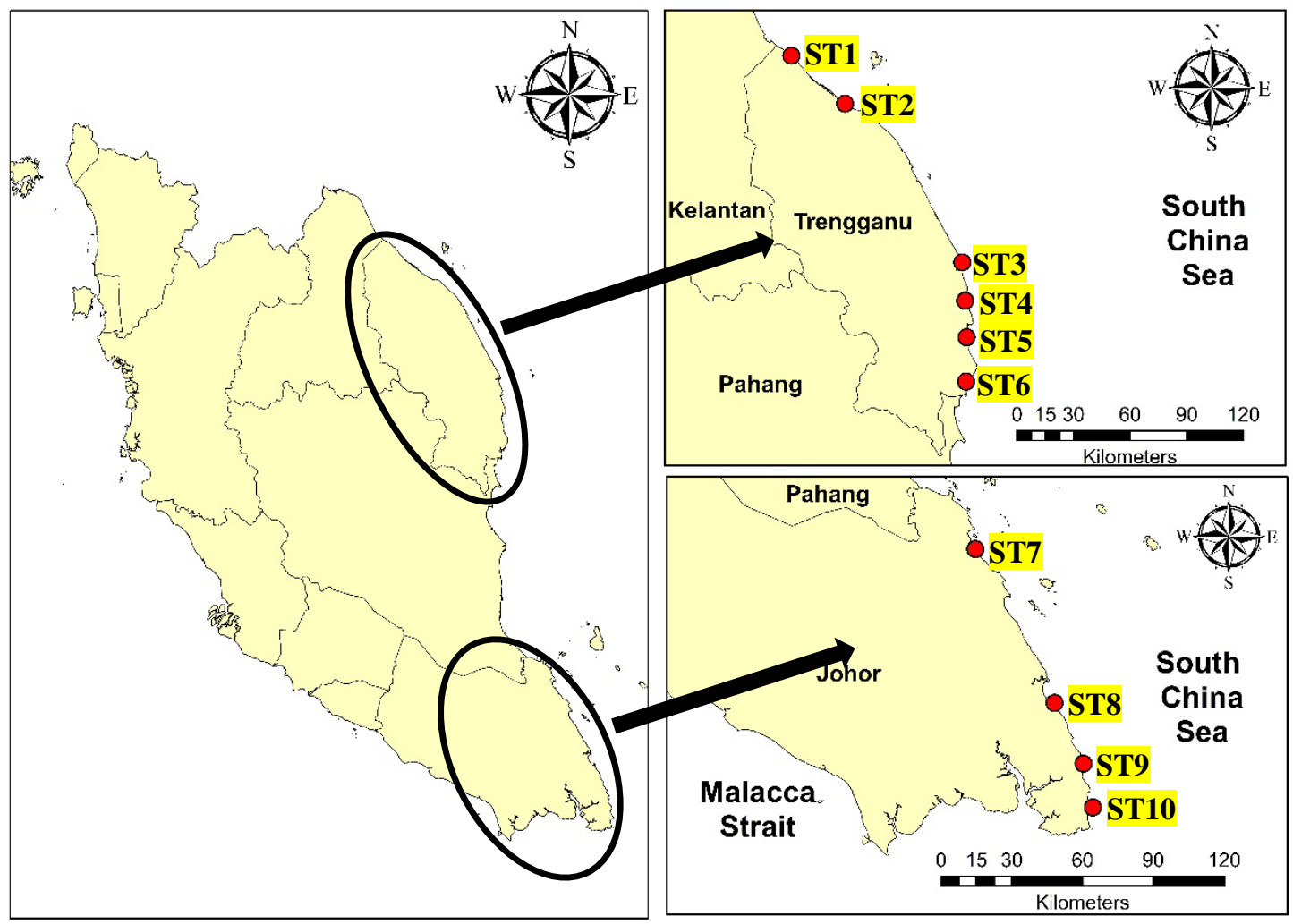

Figure 1: Location of sampling sites along Terengganu and East Johor coastal water.

Ten sites with abundant of $S$. cucullata population on natural rocky structures were selected and sampled along the Terengganu and East Johor coastal water. The sites chosen included pristine, recreational and proximity of industrial and urbanized areas in order to provide a wider range of information on bioaccumulation patterns in relation to environmental status. The location for each sampling site were recorded in Table 1 and Figure 1. About 30-35 individuals of $S$. cucullata with relatively similar size were hand collected during low tide. All samples were placed in plastic bags, sealed, labelled and stored on ice for transportation to the laboratory. At the laboratory, the samples were rinsed with running Milli-Q water to remove sediment and salt particles. Samples were stored frozen at $-20{ }^{\circ} \mathrm{C}$ until further analysis. After thawing at room temperature, samples were extracted from their shells. In order to evaluate the water content and conversion factor, wet weight of samples were recorded. Extracted soft tissues were dried in an oven at $60^{\circ} \mathrm{C}$ for 3 days before being weighed again for dry weight calculation. The dried samples were pulverized to a homogenous powder using porcelain mortar and pestle. Powder sample was stored in a desiccator at room temperature until required for analysis. The analytical procedure used to measure the REEs concentration in oysters was based on with little modification [18]. Analysis REEs were carried out using an Inductive Coupled Plasma Mass Spectrometer (ICPMS) Perkin ELMER ELAN 9000. The concentration of REEs in samples was blank corrected and expressed as $\mu \mathrm{g} \mathrm{g}^{-1}$ dry weight. The quality of method used was checked and confirmed in a separate comparative study of metals in a standard reference material, SRM BCR 668 Mussel Tissue. The analytical results were compiled using Microsoft Excel software and the statistical analysis were conducted by using SPSS software. SPSS was used for determining statistical data including oneway analysis of variance (ANOVA) and Pearson's correlation coefficient. 


\section{RESULT AND DISCUSSION}

The values of REEs concentration in soft tissue of rock oyster, S. cucullata from ten sampling sites along Terengganu and East Johor coastal water are illustrated in Figure 2. The mean of REEs' concentration for each sampling sites ranged from $0.95 \mu \mathrm{g} \mathrm{g}^{-1}$ to $4.21 \mu \mathrm{g} \mathrm{g}^{-1}$, while range for $\Sigma \mathrm{REE}$, $\Sigma \mathrm{HREE}$ and $\Sigma$ LREE is from $14.32 \mu \mathrm{g} \mathrm{g}^{-1}$ to $63.19 \mu \mathrm{g} \mathrm{g}^{-1}, 6.79 \mu \mathrm{g} \mathrm{g}^{-1}$ to $30.50 \mu \mathrm{g} \mathrm{g}^{-1}$ and $7.53 \mu \mathrm{g} \mathrm{g}^{-1}$ to $38.86 \mu \mathrm{g} \mathrm{g}^{-1}$ respectively, which indicate that LREEs is more abundance than HREEs in the tissue of rock oyster. This difference may be due to naturally lower concentrations of HREE in the environment or to the hypothesis that REE bioavailability decreases with increasing atomic number due to increasing ligand stability in HREE [22]. The presence of ligands in natural surface and pore waters decreased HREE bioavailability and hence bioaccumulation in aquatic ecosystems [23].

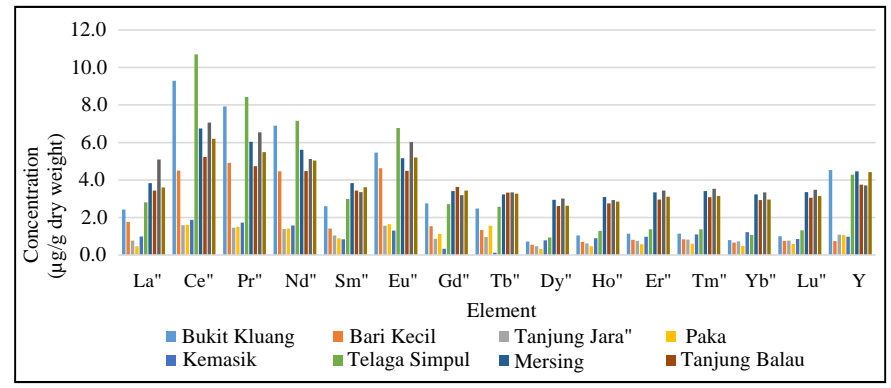

Figure 2: Concentration of Rare Earth Elements ( $\mu \mathrm{g} / \mathrm{g}$ dry weight) in soft tissue of rock oyster, $S$. cucullata from 10 sampling site along Terengganu and East Johor coastal water.

The highest and lowest mean value for $\Sigma$ LREE and LHREE are $6.48 \mu \mathrm{g} \mathrm{g}^{-1}$ at ST6 and $1.26 \mu \mathrm{g} \mathrm{g}^{-1}$ at ST4; $3.39 \mu \mathrm{g} \mathrm{g}^{-1}$ at ST7 and $0.75 \mu \mathrm{g} \mathrm{g}^{-1}$ at ST4 respectively. The pattern of $\Sigma$ REE concentration in the oyster tissue in each sampling site decreased in the order of ST10 $\left(63.19 \mu \mathrm{g} \mathrm{g}^{-1}\right)>$ ST7 $\left(61.71 \mu \mathrm{g} \mathrm{g}^{-1}\right)>\mathrm{ST} 8\left(58.10 \mu \mathrm{g} \mathrm{g}^{-1}\right)>\mathrm{ST} 6\left(55.80 \mu \mathrm{g} \mathrm{g}^{-1}\right)>\mathrm{ST} 9\left(53.88 \mu \mathrm{g} \mathrm{g}^{-1}\right)$ $>$ ST1 $\left(50.16 \mu \mathrm{g} \mathrm{g}^{-1}\right)>$ ST2 $\left(29.59 \mu \mathrm{g} \mathrm{g}^{-1}\right)>$ ST5 $\left(15.57 \mu \mathrm{g} \mathrm{g}^{-1}\right)>$ ST3 $(14.87$ $\left.\mu \mathrm{g} \mathrm{g}^{-1}\right)>$ ST4 $\left(14.32 \mu \mathrm{g} \mathrm{g}^{-1}\right)$. There are significant differences between concentrations of all REEs among sampling sites $(\mathrm{p}<0.05)$. ST7 and ST6 has the most abundance of HREEs and LREEs respectively, while ST4 has the lowest abundance for both HREEs and LREEs. In general, the abundance of REEs follow the order of $\mathrm{Ce}>\mathrm{Pr}>\mathrm{Nd}>\mathrm{Eu}>\mathrm{La}>\mathrm{Sm}$ for the LREEs and $\mathrm{Y}>\mathrm{Gd}>\mathrm{Tb}>\mathrm{Tm}>\mathrm{Er}>\mathrm{Lu}>\mathrm{Yb}>\mathrm{Ho}>$ Dy for the HREEs. The overall pattern of the REEs is $\mathrm{Ce}>\mathrm{Pr}>\mathrm{Nd}>\mathrm{Eu}>\mathrm{Y}>\mathrm{La}>\mathrm{Sm}>\mathrm{Gd}>\mathrm{Tb}>$ $\mathrm{Tm}>\mathrm{Er}>\mathrm{Lu}>\mathrm{Yb}>\mathrm{Ho}>\mathrm{Dy}$. East Johor coastal water (ST7, ST8, ST9 and ST10) has the most abundance of REEs concentration in oyster tissue compared to Terengganu coastal water. This occurrence might be due to massive urbanization and industrialization activities as well as anthropogenic activities such as discharged of organic materials and contaminations from boating and fishing activities, agricultural, aquaculture and industrial wastes and municipal effluents found in high population areas of East Johor.

Ce $\left(5.48 \mu \mathrm{g} \mathrm{g}^{-1}\right)$ is the most abundance elements and Dy $\left(1.50 \mu \mathrm{g} \mathrm{g}^{-1}\right)$ is the least abundance elements in the tissue of $S$. cucullata. Oyster from ST6 has the highest concentration of $\mathrm{Ce}\left(10.70 \mu \mathrm{g} \mathrm{g}^{-1}\right)$ and the lowest concentration of Dy $\left(0.32 \mu \mathrm{g} \mathrm{g}^{-1}\right)$ is at ST4. Ce is the most abundance elements because it has lower and even atomic number, thus has more abundance of the element concentration in the environment. A researcher analyzed that, elements with lower and even atomic number is higher in concentration compared to elements with higher and odd atomic number [24]. Table 2 shows that all REEs were found to have positive correlation among each other resulting from their physicochemical properties (trivalent, electropositive and insoluble) and geochemical behaviour similarities and expected to be similar as well in their distribution pattern in biological tissue hence, behave coherently in various geochemical fractionation processes $[18,22]$.

Table 2: Inter-REE possible associations in the oyster tissue using Pearson's correlation coefficient

\begin{tabular}{|c|c|c|c|c|c|c|c|c|c|c|c|c|c|c|c|}
\hline & $\mathrm{La}$ & $\mathrm{Ce}$ & $\mathrm{Pr}$ & $\mathrm{Nd}$ & $\mathrm{Sm}$ & $\mathrm{Eu}$ & $\mathrm{Gd}$ & $\mathrm{Tb}$ & Dy & Ho & Er & $\mathrm{Tm}$ & $\mathrm{Yb}$ & $\mathrm{Lu}$ & $\mathrm{Y}$ \\
\hline $\mathrm{La}$ & 1 & & & & & & & & & & & & & & \\
\hline $\mathrm{Ce}$ & $.658^{*}$ & 1 & & & & & & & & & & & & & \\
\hline $\mathrm{Pr}$ & $.707^{*}$ & $.988^{* *}$ & 1 & & & & & & & & & & & & \\
\hline $\mathrm{Nd}$ & $.693^{*}$ & $.979^{* *}$ & $.992^{* *}$ & 1 & & & & & & & & & & & \\
\hline Sm & $.923^{* *}$ & $.730^{*}$ & $.748^{*}$ & $.770^{* *}$ & 1 & & & & & & & & & & \\
\hline $\mathrm{Eu}$ & $.808^{* *}$ & $.937^{* *}$ & $.967^{* *}$ & $.960^{* *}$ & $.820^{* *}$ & 1 & & & & & & & & & \\
\hline Gd & $.891^{* *}$ & $.724^{*}$ & $.752^{*}$ & $.777^{* *}$ & $.977^{* *}$ & $.827^{* *}$ & 1 & & & & & & & & \\
\hline $\mathrm{Tb}$ & $.882^{* *}$ & $.673^{*}$ & $.697^{*}$ & $.710^{*}$ & $.950^{* *}$ & $.788^{* *}$ & $.982^{* *}$ & 1 & & & & & & & \\
\hline Dy & $.900^{* *}$ & .334 & .381 & .391 & $.861^{* *}$ & .517 & $.810^{* *}$ & $.811^{* *}$ & 1 & & & & & & \\
\hline Ho & $.908^{* *}$ & .399 & .438 & .456 & $.902^{* *}$ & .565 & $.852^{* *}$ & $.844^{* *}$ & $.995^{* *}$ & 1 & & & & & \\
\hline $\mathrm{Er}$ & $.917^{* *}$ & .384 & .427 & .438 & $.888^{* *}$ & .559 & $.838^{* *}$ & $.839^{* *}$ & $.998^{* *}$ & $.998^{* *}$ & 1 & & & & \\
\hline $\mathrm{Tm}$ & $.910^{* *}$ & .362 & .405 & .415 & $.876^{* *}$ & .538 & $.824^{* *}$ & $.825^{* *}$ & $.999^{* *}$ & $.997^{* *}$ & $.999^{* *}$ & 1 & & & \\
\hline $\mathrm{Yb}$ & $.874^{* *}$ & .281 & .324 & .334 & $.827^{* *}$ & .461 & $.766^{* *}$ & $.765^{* *}$ & $.997^{* *}$ & $.988^{* *}$ & $.991^{* *}$ & $.995^{* *}$ & 1 & & \\
\hline Lu & $.907^{* *}$ & .360 & .403 & .414 & $.880^{* *}$ & .542 & $.835^{* *}$ & $.841^{* *}$ & $.998^{* *}$ & $.996^{* *}$ & $.999^{* *}$ & $.999^{* *}$ & $.991^{* *}$ & 1 & \\
\hline $\mathrm{Y}$ & $.794^{* *}$ & $.845^{* *}$ & $.824^{* *}$ & $.840^{* *}$ & $.927^{* *}$ & $.809^{* *}$ & $.908^{* *}$ & $.874^{* *}$ & $.665^{*}$ & $.726^{*}$ & $.705^{*}$ & $.689^{*}$ & .626 & $.690^{*}$ & 1 \\
\hline
\end{tabular}

The distribution pattern of REEs' concentration in S. cucullata is similar even though, there are variation in their concentration values among sampling sites which suggest that they are of similar origin. Significant variation between sites may be attributed to biological variation within the oysters and differences in lanthanide availability between sites. REEs are considered as non-essential metals due to their unestablished biological function eventhough, they are proven to be taken up by oyster. Different uptake sources are not taken into account as $S$. cucullata takes up lanthanides from surface water by filter-feeding behaviour [18]. However, stated in some study suggests that REE availability in the habitat is not the only factor contributing to the variability $[23,25]$. As the oyster were collected in rural areas as well as close to cities, the oysters likely experienced different substrates and to a lesser extent, different $\mathrm{pH}$ and temperature conditions, which all may have contributed to the variability observed in $\Sigma$ REE.
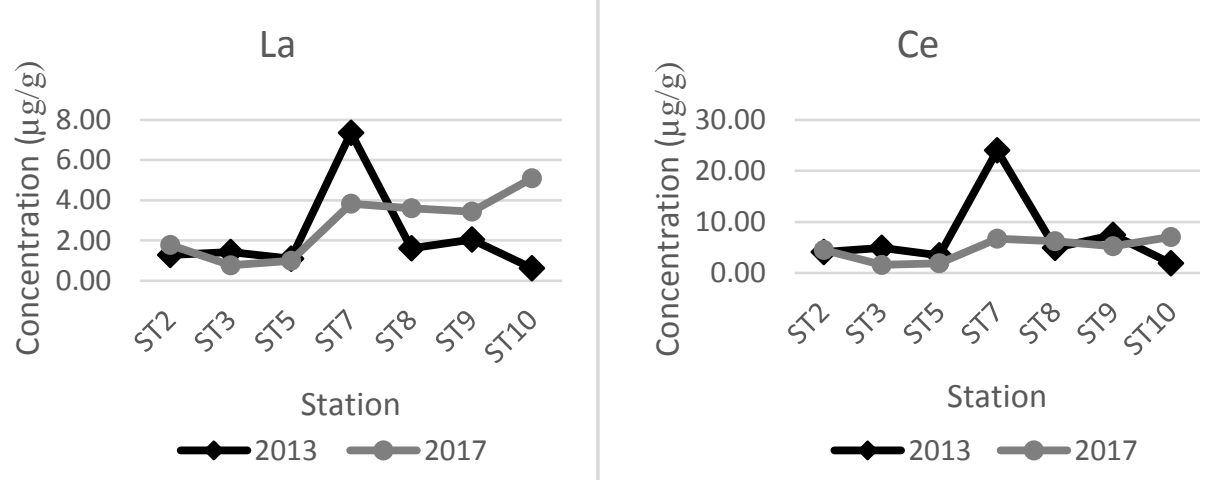


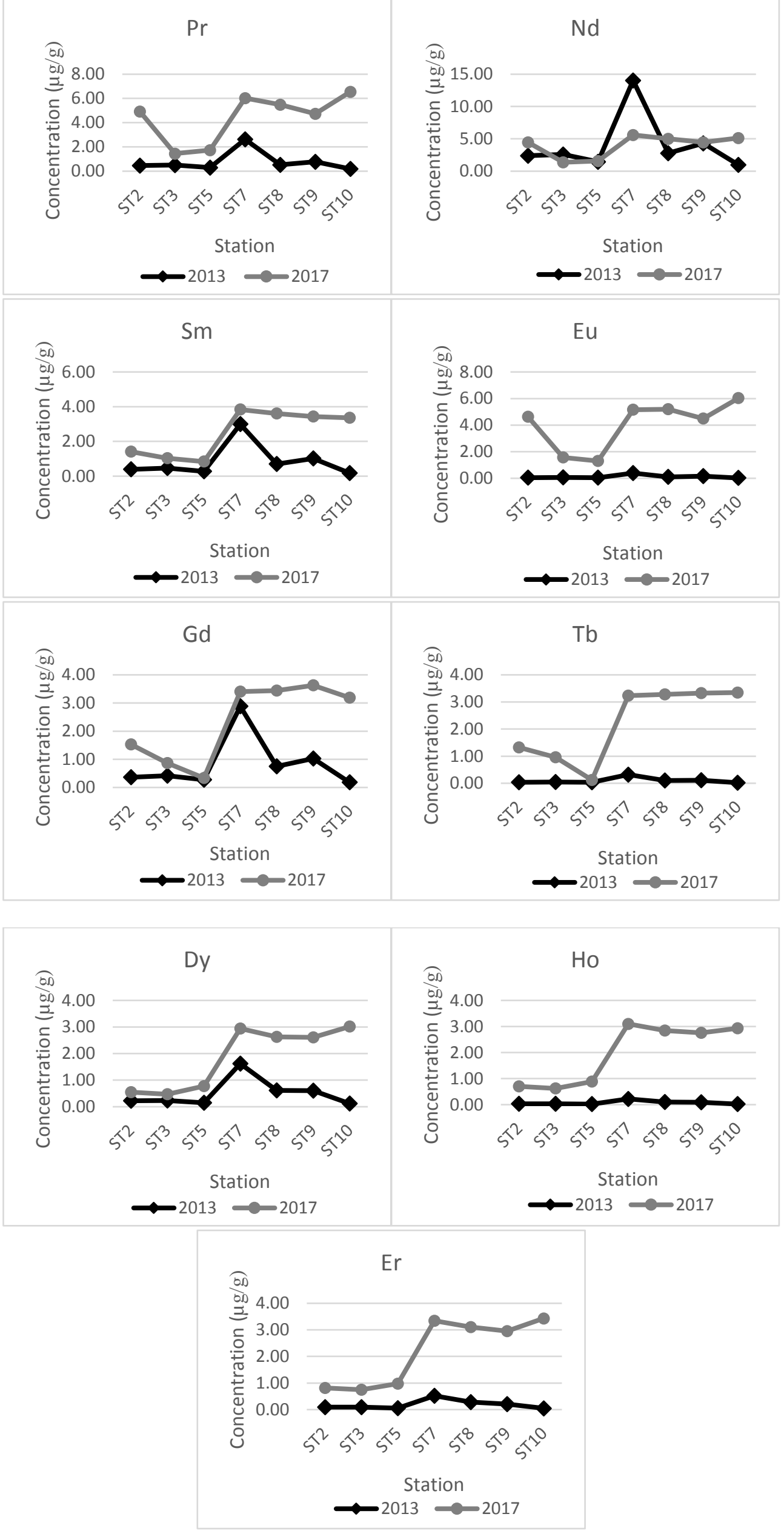




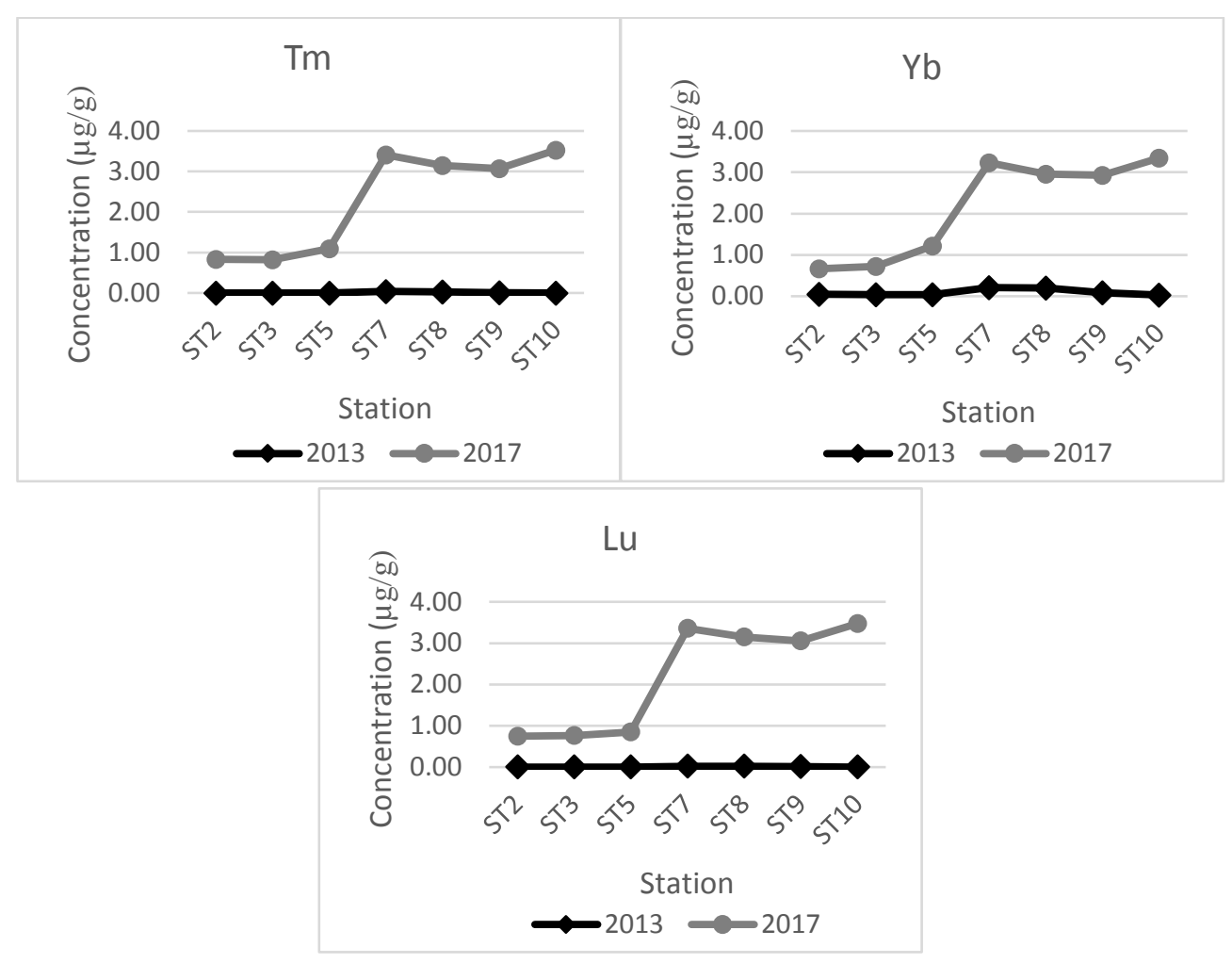

Figure 3: Concentration of Rare Earth Elements ( $\mu \mathrm{g} / \mathrm{g}$ dry weight) in soft tissue of rock oyster, Saccostrea cucullata from 7 sampling site along Terengganu and East Johor coastal water in the year of 2013 and 2017.

In comparison with study done, there is a significant difference between concentration of all REEs in the year of 2013 and 2017 except for La, Ce and Nd ( $\mathrm{p}<0.05)$ [18]. Figure 3 shows the concentration of REEs in soft tissue of S. cucullata in the year of 2013 and 2017 from ST2, ST3, ST5, ST7, ST8, ST9 and ST10. The concentration of REEs in these seven sampling sites has shown increasing values of REEs' concentration except for La, Ce and Nd from 2013 to 2017. Concentration of La, Ce and Nd at ST7 in 2017 indicate a very significant decrease compared from 2013 [15]. The distribution pattern of REEs concentration in this study is slightly different [21]. This is probably due to the fluctuation of environmental parameters such as $\mathrm{pH}$ and temperature that affect the speciation of REEs in coastal water via their impact on the activity of $\mathrm{CO}_{3}{ }^{2-}$ and hence impacted the amount of free REEs ${ }^{3+}$ available for uptake by the mussels [26]. The differences of REEs' concentration in soft tissue of $S$. cucullata in the year of 2013 and 2017 in East Johor coastal water is bigger compared to Terengganu coastal water. The trend for REEs' concentration in 2013 and 2017 also shown LREEs' enrichment over HREEs in soft tissue of $S$. cucullate [27]. The enrichment of REEs' concentration in East Johor coastal water may be due to anthropogenic factors introduced by human activities resulting from urbanization and industrialization activities in the vicinity which rose rapidly by year especially in ST7.

\section{CONCLUSION}

Concentration of REEs in soft tissue of $S$. cucullata in East Johor coastal water is more abundance compared to in soft tissue of $S$. cucullata in Terengganu coastal water. Ce has the highest average concentration among REEs while, Dy has the lowest concentration among REEs. Bioaccumulation patterns in soft tissue of rock oyster is consistent throughout the sampling sites which indicate that they are from similar origin even thought their abundance are vary from each sampling sites. The distribution pattern of REEs' concentration suggested that the fractionation of REEs in coastline marine environment shows some preferential incorporation of LREE over HREE. ST10 in East Johor has the most abundance of REEs in soft tissue of $S$. cucullata while, ST4 has the lowest abundance of REEs. REEs are naturally occurrence in the environment, but massive urbanization and industrialization activities as well as anthropogenic activities contribute in the increment of REEs concentration. The distribution pattern of REEs' concentration in soft tissue of $S$. cucullata in this study is slightly different.

\section{ACKNOWLEDGEMENT}

The author thanks the Ministry of Education Malaysia and International Islamic University Malaysia for providing Fundamental Research Grant Scheme (FRGS16-040-0539) and facilities

\section{REFERENCES}

[1] Wang, L., Liang, T. 2015. Geochemical fractions of rare earth elements in soil around a mine tailing in Baotou, China. Scientific Reports, 5, 12483; doi: $10.1038 /$ srep 12483 .

[2] Zhuang, M., Wang, L., Wu, G., Wang, K., Jiang, X., Liu, T., Chu, Z. 2017. Health risk assessment of rare earth elements in cereals from mining area in Shandong, China. Scientific Reports, 7 (1), 1-6. https://doi.org/10.1038/s41598-017-10256-7

[3] Long, K.R., Van Gosen, B.S., Foley, N.K., Cordier, D. 2012. The principal rare earth elements deposits of the United States: a summary of domestic deposits and a global perspective. Springer, Netherlands.

[4] Rezaee, K., Saion, E., Wood, A.K., Abdi, M. 2010. Rare earth elements determination and distribution patterns in surface marine sediments of the South China Sea by INAA, Malaysia. Journal of Radioanalytical and Nuclear Chemistry, 283 (3), 823-829.

[5] Du, X., Graedel, T.E. 2011. Uncovering the Global Life Cycles of the Rare Earth Elements. Scientific Reports, 1, 145; DOI:10.1038/srep00145.

[6] Heitland, P., Koster, H.D. 2006. Biomonitoring of 30 trace elements in urine of children and adults by ICP-MS. Clinica Chimica Acta, 365, 310318.

[7] Wang, J., Zhou, G., Chen, C., Yu, H., Wang, T., Ma, Y., Jia, G., Gao, Y., Li, B., Sun, J. 2007. Acute toxicity and biodistribution of different sized titanium dioxide particles in mice after oral administration. Toxicology Letters, 168, 176-185. 
[8] Jiang, D.G., Yang, J., Zhang, S., Yang, D.J. 2012. A survey of 16 rare earth elements in the major foods in China. Biomedical and Environmental Sciences, 25, 267-271.

[9] Hao, Z., Li, Y., Li, H., Wei, B., Liao, X., Liang, T., Yu, J. 2015. Levels of rare earth elements, heavy metals and uranium in a population living in Baiyun Obo, Inner Mongolia, China: A pilot study. Chemosphere, 128, 161-170.

[10] Pagano, G. 2015. Rare earth elements in human and animal health: State of art and research priorities. Environmental Research, 142, 215220.

[11] Waring, P.M., Watling, R.J. 1990. Rare earth deposits in a deceased movie projectionist. The Medical Journal of Australia, 153, 726-730.

[12] Pairon, J.C., Roos, F., Sebastien, P. 1995. Biopersistence of cerium in the human respiratory tract and ultrastructural findings. American Journal of Industrial Medicine, 27, 349-358.

[13] Zaichick, S., Zaichick, V., Karandashev, V., Nosenko, S. 2011. Accumulation of rare earth elements in human bone within the lifespan. Metallomics, 3, 186-194.

[14] Riondato, J., Vanhaecke, F., Moens, L., Dams, R. 2001. Determination of rare earth elements in environmental matrices by sector-field inductively coupled plasma mass spectrometry. Fresenius Journal of Analytical Chemistry, 370, 544-552.

[15] Fuad, M.M., Shazili, N.A.M., Faridah, M., Kamaruzzaman, Y. 2014. Trace Metals in Thais clavigera along coastal waters of the East Coast of Peninsular Malaysia. Malaysiana Science, 43 (4), 529-534.

[16] Tanabe, S., Subramanian, A. 2003. Biomarkers and Analytical Methods for the Analysis of POPs in Developing Countries, STAP/GEF and Ministry of Environment, Government of Japan (Sponsored) STAP Workshop on The Use of Bioindicators, p. 1.

[17] Zhou, Q., Zhang, J., Fu, J., Shi, J., Jiang, G. 2008. Biomonitoring: An appealing tool for assessment of metal pollution in the aquatic ecosystem. Analytica Chimica Acta, 606 (2), 135-150.

[18] Amin, B., Ismail, A., Arshad, A., Yap, C.K., Kamarudin, M.S. 2006. A comparative study of heavy metal concentrations Nerita lineata from the intertidal zone between Dumai, Indonesia and Johor,Malaysia. Journal of Coastal Development, 10, 19-32.

[19] Shazili, N.A.M., Yunus, K., Ahmad, A.S., Abdullah, N., Rashid, M.K.A. 2006. Heavy metal pollution status in the Malaysian aquatic environment. Aquatic Ecosystem Health \& Management, 9 (2), 137-145.

[20] Yap, C.K., Cheng, W.H., Ismail, A., Ismail, A.R., Tan, S.G. 2009. Biomonitoring of heavy metal $(\mathrm{Cd}, \mathrm{Cu}, \mathrm{Pb}$, and $\mathrm{Zn}$ ) concentrations in the west intertidal area of Peninsular Malaysia by using Nerita lineata. Toxicological \& Environmental Chemistry, 91 (1), 29-41.

[21] Fuad, M.M., Shazili, N.A.M., Faridah, M. 2013. Trace metals and rare earth elements in Rock Oyster Saccostrea cucullata along the east coast of Peninsular Malaysia. Aquatic Ecosystem Health and Management, 16 (1), 78-87. Doi: 10.1080/14634988.2013.762327.

[22] MacMillan, G.A., Ch'etelat, J., Heath, J.P., Mickpegak, R., Amyot, M. 2017. Rare earth elements in freshwater, marine and terrestrial ecosystems in the eastern Canadian Arctic. Environmental Science: Processes \& Impacts. Doi: 10.1039/c7em0082k.

[23] Weltje, L., Heidenreich, H., Zhu, W., Wolterbeek, H.T., Korhammer, S., Goeij J.J.M.d., Markert, B. 2002. Lanthanide concentrations in freshwater plants and molluscs, related to those in surface water, pore water and sediment. A case study in The Netherlands. Science of The Total Environment, 286 (1-3), Pp. 191-214.

[24] Voncken, J.H.L. 2016. The Rare Earth Elements. Springer International Publishing. Geochemistry. ${ }^{\text {st }}$ E. X, 127. Doi: 10.1007/978-3-319-26809-5.

[25] Merschel, G., Bau, M. 2015. Rare earth elements in the aragonitic shell of freshwater mussel Corbicula fluminea and the bioavail ability of anthropogenic lanthanum, samarium and gadolinium in river water. Science of the Total Environment, 533, 91-101.

[26] Ponnurangam, A., Bau, M., Brenner, M., Koschinsky, A. 2016. Mussel shells of Mytilus edulis as bioarchives of the distribution of rare earth elements and yttrium in seawater and the potential impact of ph and temperature on their partitioning behaviour. Bio geosciences, 13, 751760. Doi: 10.5194/bg-13-751-2016 